\title{
Social Construction of Authorized Users in the Digital Age
}

\section{Xiaohua Zhu and Kristin R. Eschenfelder}

This paper analyzes changes to the definitions of "authorized users" contained in electronic resources licenses and embedded in access control technologies from the mid-1990s to the present. In analyzing changes to the license and technology-based definitions, it tracks shifts in major stakeholders' perceptions of authorized users and describes developments in licensing and access control technologies. The paper demonstrates that the concept of authorized users has been shaped by a mix of social and technical elements, including changes to information providers' and libraries' business models and missions, shifts in norms for license terms, and development of technological tools used to facilitate or constrain access.

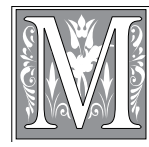

any Internet enthusiasts initially believed that information technologies and the digitization of scholarly scientific and cultural works would expand access to information and promote information equality. ${ }^{1}$ Within the academic libraries context, one could argue that this optimistic vision of the information age has come true-since the mid-1990s, publishers have made an ever-widening array of fulltext scholarly information available on the Internet through increasingly convenient publication delivery platforms. Yet this perception of expanded access brought on by e-resources is more complex than it initially appears. For example, members of the public who enter an academic library may now be required to register for a guest ID to log in to library terminals and use e-resources - resources that in a print environment they could pluck from the shelves without mediation or registration. Moreover, new technologies like Shibboleth raise the possibility of fine-grained access restrictions that simultaneously challenge libraries' missions of wide access while dangling the promise of reduced costs. It is important to take time to reflect on how the shift to e-resources have changed the terms under which various user groups can access and use scholarly content and to consider the contradictions and challenges raised by those changes.

This paper traces changes in access terms for scientific and cultural works marketed to academic libraries by commercial and scholarly society information providers ("providers") including publishers, vendors, and aggregators from the mid-1990s to the present. It tracks changes

Xiaohua Zhu is a Ph.D. candidate in the School of Library and Information Studies at the University of Wisconsin-Madison; e-mail: xzhu2@wisc.edu. Kristin R. Eschenfelder is Associate Professor in the School of Library and Information Studies at the University of Wisconsin-Madison; e-mail: eschenfelder@wisc. edu. (c) Xiaohua Zhu and Kristin R. Eschenfelder 
in stakeholder perceptions of who should be allowed to use the resources-or who is an "authorized user" - and related developments in licensing and access control technologies that materialized those perceptions. Public college and university libraries are the primary focus because these libraries, more so than private colleges and universities, must balance the access needs of their primary academic community with those of the surrounding "public" community-a tension key to debates about authorized users.

The paper demonstrates that answers to questions about who can access library e-resources, or who is an "authorized user," are shaped by a complex mix of social and technical elements that cannot easily be separated from one another: They are "socio-technical." ${ }^{2}$ It is not simply a question of technology: People design access control technologies to facilitate certain actions and prevent others. In doing so, the technology is said to "embed" values, policies, and goals. ${ }^{3}$ This raises questions about the consequences of the actions that technologies prevent or facilitate and the fairness of the values that technologies embed. But it is also not simply a question of policy: The paper will demonstrate how license terms defining authorized users have been greatly influenced by the access control technologies of the day. Policies shifted as underlying technologies made new uses, or new restrictions, possible. Examination of the reciprocal relationship between the social and the technical - or the sociotechnical mix - is important to understanding changes in authorized users during the period of study. The mix includes information providers' and libraries' business models and missions, license terms, and development of new technological tools that could be used to facilitate or constrain access.

In reviewing the short history of the concept of "authorized users" of scholarly information at U.S. public colleges and universities, this paper explores how stakeholders' conceptualizations of au- thorized users have changed over time and how changing conceptualizations, license terms, and development of access control technologies have interacted to mediate who could use e-resources. The history of access controls highlights important tensions between knowledge as a public good versus knowledge as a commodity, and points to problems of supporting public access to e-resources that remain unresolved in contemporary academic librarianship. This history will help information professionals better understand the implications of present-day and future access restrictions on scholarly information. Further, it may help libraries to argue for more liberal access rules in license negotiations, or for more funding to support robust and unmediated public access to knowledge in an increasingly electronic environment.

The paper draws on three theoretical concepts to aid in the interpretation of changes in conceptions of authorized users and to clarify the relationships between conceptions, license terms, and access control technologies. Drawing on Wiebe E. Bijker's concept of interpretive flexibility, this research traces stakeholders' conceptualization of authorized users through a process of both contention and mutual education, in which two groups with initially divergent conceptions developed temporary shared understandings. ${ }^{4}$ In this process, license agreements can be seen as what Susan L. Star has called boundary objects. Star describes boundary objects as a platform for negotiation between libraries and information providers to support the shared goal of providing information resources to the public. Boundary objects are also an inscription of the temporary shared understanding of who can access and use licensed resources in that we can examine past license terms for clues to past assumptions and shared understandings. ${ }^{5}$ Finally, the technological and policy tools maintained between publishers and libraries to enforce access rules (such as proxy servers) can be seen as what Tarleton Gillespie refers to as 
regimes of alignment or social arrangements developed between institutions to support technological access controls to intellectual property. The coordination of technology, policies, and management processes between libraries and providers create a regime of alignment between them. ${ }^{6}$

This paper continues by describing the research design and data collection and analysis methods. The findings section interprets the data through the three theoretical concepts introduced above. Finally, a discussion and summary of the themes of this paper is provided with suggestions for future research.

\section{Methodology}

This paper employs a historical analysis research strategy. Historical research is particularly suitable for developing a rich understanding of a social world, for examining the past as a means to understand the present, and for explaining how and why the present came to be. ${ }^{7}$

Following the tradition of historical research, this study relies heavily on primary sources to understand both the context and the phenomenon from practitioners' perspectives. ${ }^{8}$ Sources include key stakeholders' discussions of electronic publishing and licensing during the study period. For example, the "Liblicense-L" discussion list archive has recorded the discussions of licensing issues since January 1997. ${ }^{9}$ Other sources include trade journals and newsletters of the information industry, articles in library professional journals, and conference proceedings in the library field and the publishing industry. ${ }^{10}$

In addition to the above textual data sources, the paper draws on data from eighteen interviews with academic librarians and staff of information providers involved with licensing e-resources. ${ }^{11}$ The interviews, conducted between March 2007 and August 2008, were semistructured in nature and asked participants to reflect on past and present licensing practice. The participants were purposefully selected to include representatives from public and private academic libraries of different sizes. ${ }^{12}$

In the process of reviewing, analyzing, and interpreting the historical and interview data, we employed the research strategies of triangulation and crystallization. ${ }^{13}$ Triangulation suggests combination of multiple data sources (such as interviews and secondary document review) and analysis techniques (like content analysis and narrative analysis) as a cross-check for internal consistency and reliability. ${ }^{14}$ Crystallization is a research stance that attempts to reflect the complexity of social reality and the varying interpretive viewpoints of study participants. In using crystallization, the aim of research is to uncover and report a variety of viewpoints rather than a single fixed reality. ${ }^{15}$ It aims to explain complexity by highlighting the socially constructed meanings. ${ }^{16}$ Using these research strategies, we coalesced data from the different sources, hand-coded it, and then sorted data into inductive categories. We then used the social theories described above to assist in interpreting the emergent multidimensional themes.

\section{Changes to Conceptions of Authorized Users}

This section uses the three theoretical lenses introduced above (interpretive flexibility, boundary objects, and regime of alignment) to explore changes to conceptions of authorized users and the development of access control technologies from the mid-1990s to the present. For each concept, a vocabulary and framework are provided, and then the historical analysis follows.

\section{Relevant Social Groups and the Interpretive Flexibility of Authorized Users Bijker's social construction of technology (SCOT) theory suggests that, to under- stand the success or failure of technolo- gies (broadly defined), we should look to the social interactions within and among the relevant social groups engaging with}


the technology rather than examine the technology itself. Each social group interprets a technology according to its own circumstances. Consequently, a technology is said to have "interpretive flexibility." Different social groups might have different opinions as to whether a technology is "working" or "nonworking," or even what a technology means. In time, however, interpretive flexibility may come to closure if multiple relevant social groups reach a consensus about the meaning and utility of a technology. ${ }^{17}$

From a SCOT perspective, academic libraries and information providers represent different social groups whose conceptions of authorized users have slowly moved toward closure from the mid-1990s to the present. Libraries and providers have come to share conceptions and cooperate in the development and maintenance of access control technologies. But during this period, many aspects of the definition of authorized users were in conflict: "working" models of authorized users in one group may have been "nonworking" in the other group. This section analyzes factors that led stakeholders to conceptualize authorized users differently and to change their conceptualizations over time.

\section{Users of Academic Libraries}

Libraries have always played an important role in defining authorized users and determining access to information. For centuries, libraries restricted use of collections to aristocrats, social elites, or the religious ordained. ${ }^{18}$ However, contemporary American academic libraries tend to emphasize an ideology of intellectual freedom and equal access, with some variation between private and public academic library types. Academic libraries have a targeted user base, but many-especially those at public or land grant institutions-believe that it is their responsibility to "carr[y] out an advocacy role for the widest possible access to information."19 Private college and university academic libraries may be less subject to this tension.
The scope of a public academic library's user community (that is to say, academic librarians' conception of users) has changed over time. Traditionally, an academic library's core clients included faculty, students, and staff. From the eighteenth century to the mid-twentieth century, the library's mission was to provide "local access to local physical holdings for a local community." 20 After World War II, academic libraries transcended their traditional role and assumed more social functions and offered more outreach services to broaden their user communities. ${ }^{21}$ The results of a 1967 nationwide survey indicated that most responding college and university libraries in the United States permitted in-building use of materials by external users, 85 percent extended circulation privilege to external users, and nearly half of them granted the library privilege to "all persons." 22 In this mid-century print environment, academic libraries' conception of user comprised not only faculty, students, and staff but also other users: retired personnel, alumni, donors, friends of the library, and even the general public. Importantly, small businesses and researchers from local companies often used academic libraries to gain access to high-priced literature. ${ }^{23}$

In the twentieth-century paper world, authorized-user definitions were largely implicit and for the most part included all those who physically visited the library: “...until the advent of licensing, authors and publishers rarely questioned who the library user would be or where, how often, and for what purposes their work would be used." ${ }^{24}$ Questions about authorized users of paper items were largely framed in terms of interlibrary loan debates (Could a book be sent to a user at another library?) or photocopying (Could a patron photocopy an item and use outside the library?).

\section{Divergence in Conceptions about Authorized Users}

In the 1980s, scholarly journal publishing began its shift from print to electronic 
formats, and this shift, along with the rise of networking, created new questions about who was authorized to use electronic materials. Academic libraries were quick to embrace electronic formats such as tape leases, online services, and CD-ROMs because these resources saved space and users' time, and they were highly searchable. ${ }^{25}$

In the process of "selling" e-resources, providers required that libraries sign license agreements that defined - among other things - who could access the eresources, or the "authorized users" of the resource. Defining authorized users generated a tension: Narrow definitions could exclude users, forcing them to buy their own access and potentially increasing sales. But narrow definitions could also create dissatisfaction and ill will among library customers.

Many providers defined authorized uses by restricting access to "internal users" of academic libraries. ${ }^{26}$ It was unclear in many instances if the internal users specifically included the public. After all, prior to the maturation of campus networks, using an e-resource still required a physical trip to the library-therefore all campus users, including walk-in users, were internal to the library building and met the internal user requirement. Some providers explicitly included the public in their definitions; for example, an early license agreement of DIALOG OnDisc (a CD-ROM product by DIALOG) specifically stated that, in the case of educational institutions, public access was allowed. ${ }^{27}$ Some providers may have been more restrictive due to lack of experience with academic libraries or concerns about loss of potential sales to public users. But, in general, the definitions of internal users were vague enough for academic libraries to continue to permit many different types of users.

Libraries' and providers' definitions of authorized users diverged as desktop computers became more common and local area networking developed in the 1990s. Libraries began to provide campus network access to e-resources, expanding their conception of authorized users beyond those users physically visiting the library. Libraries' conception of authorized users became detached from a user's physical presence in the library.

The networking of e-resources generated concern among providers because networking could facilitate unauthorized copying and dissemination, which could reduce subscription revenue. ${ }^{28}$ Rapid advances in network speeds made it easier to download full-text content; further, digital information could be easily disseminated over the Internet. ${ }^{29}$ These concerns led providers to tighten their definition of authorized users in license agreements for networked access. Some providers' licenses began to include user definitions with the following characteristics:

1. An academic library was as an institution customer who should have a physical location, or a "site."

2. Users should be affiliated with the academic institution that paid for the product, typically faculty, staff, and students.

3. Users' working locations should be on campus, and the users should access information from their working locations via the oncampus networks. ${ }^{30}$

Information providers' exploration of new business models and pricing strategies likely encouraged a narrower conception of authorized users as described above. In transitioning from print to digital publishing, providers began to experiment with a range of pricing and distribution models and license terms. ${ }^{31}$ Many providers adopted price differentiation strategies based on access characteristics such as the number of full-time employees, the number of students, the number of workstations, or the number of concurrent users allowed..$^{32}$ As variations in access became a product feature and pricing point, questions about who should have access became more important. $^{33}$ 
Meanwhile, many information providers hoped to expand to the end-user market under a pay-per-view business model. ${ }^{34}$ For example, in 1991, Collier, a British publisher, predicted that 99 percent of potential information users were end users who would individually purchase information. ${ }^{35}$ Wider access to e-resources from academic libraries could compete with attempts to market information directly to end users. It therefore became typical in the late 1990s for providers to require that users "must be affiliated with a subscribing institution." 36

Information providers' conceptions about authorized users were also likely affected by their existing business practices and profit streams. In the 1990s, most publishers continued to rely on print revenue for profits; it was uncertain when electronic versions of products would generate revenue. ${ }^{37}$ During this period, many publishers feared that liberal electronic access would discourage continuation of individual faculty and researchers' print subscriptions, thereby reducing overall revenue. ${ }^{38}$

Furthermore, some providers' prior experience with the corporate world may have shaped their expectations about definitions of sites and users. The primary market of many providers was not academic libraries, but rather professional groups, information centers, or special libraries in corporations and research centers. ${ }^{39}$ Narrowly defined sites and personnel acceptable in these environments proved more problematic in the academic library environment. ${ }^{40}$ When these information providers began to license products to libraries, they may have used the narrower definitions originally created for corporate customers, definitions whose terms did not fit academic libraries as well. ${ }^{41}$

From a SCOT perspective, the networking of information products in the 1990s increased the interpretive flexibility of "authorized users." During this period, libraries generally sought to expand the definition of authorized users to include new use scenarios afforded by networking, but some providers were less enthusiastic about this expansion and contractually defined a more limited set of users through licenses. They also began to employ access control technologies to define users. Licensing and access control technologies are discussed in the following sections.

\section{License Agreements as Boundary Objects}

Information providers adopted "licensing," or leasing of access rights to customers, to overcome what the information industry saw as the insufficient protection provided by copyright law. ${ }^{42}$ During a licensing transaction, both parties negotiate terms for, and then sign, a legal contractthe license agreement. The license defines the rights, restrictions, and responsibilities of each party, including definitions of authorized users, authorized sites, and users' rights. Both parties are bound by the license terms.

License agreements are a type of "boundary object" that facilitates cooperation between two groups whose field-specific constraints and worldviews might otherwise hinder cooperation. They serve as an interface or a "blackboard" for communication and interaction. ${ }^{43}$ From a historical perspective, they also serve as representations of the expectations and norms of the day for various types of rights, restrictions, and responsibilities. Changes in norms and expectations can be traced through changes in license terms.

The use of license agreements in library-provider relationships dates back to use of databases and computer software in the 1970s, when customers signed simple contracts before using these information products. ${ }^{44}$ Based on this experience, libraries usually accepted early e-resource licenses, including their definitions of authorized users, without negotiation, seeing them as equivalent to nonnegotiable software licenses. ${ }^{45}$ Commentators of the day described how many librarians assumed that they 
had only two options: either accept all of the license terms or reject the license altogether. ${ }^{46}$

But several factors in the early 1990s led to increased negotiation of license terms. First, e-resources' growing importance and librarians' increasing experience with licenses led to more questioning of license terms ${ }^{47}$ Librarians began to wonder whether some restrictive information providers really understood what they were asking of their library customers. ${ }^{48}$ Further, the highly cooperative example of JSTOR, which encouraged library input into its license terms, shifted academic librarians' expectations about license development. ${ }^{49}$ Librarians began to ask providers for changes in licenses, and, through these actions, licenses shifted from being nonnegotiable statements of access and use terms to malleable representations of mutual understandings. As licensing expert Ann Okerson stated, "Institutional electronic content licenses are now generally regarded as negotiable, mostly because the library-customer side of the marketplace has treated them as such." ${ }^{50}$ A review of the literature shows a spurt of "how to" information on license negotiation starting in the mid-1990s; subsequently, license negotiation has served as one of the primary means of establishing mutually agreed-upon access terms for e-resources.

Library licensing guidebooks and articles from the mid-1990s to the present all suggest that librarians review "authorized user" terms with special attention. ${ }^{51}$ They suggest scrutiny of providers' techniques for counting users, restrictions on user location, and descriptions of how the access may be provided. ${ }^{52}$ Some warned that definitions of users were sometimes embedded in the definitions of "site." 53 Some cautioned that narrower definitions might require library enforcement or restrict networking options. ${ }^{54}$

This section continues by outlining two areas in license negotiations between libraries and providers important to the changes in conceptions of authorized us- ers: whether or not the public and alumni qualified as authorized users, and the physical location of a "site."

\section{The Public and Alumni as Authorized Users}

As e-resources became available over networks, public users became a controversial user group. As explained earlier, many early license agreements for networked resources limited "authorized users" to students, employees, or teaching staff. Organization affiliation was a common requirement: It was typical for information providers to state that users "must be affiliated with a subscribing institution." 55 For example, "the user must be... either employees or registered patrons" and "[a]ffiliates are the registered students and faculty of the institution." ${ }^{56}$ In some cases, licenses of some products limited usage to faculty or students of a particular department or school. ${ }^{57}$ In another example, license language restricting use to "noncommercial" applications and "academic research" seemingly excluded any walk-in business use. ${ }^{58}$ The public was not able to enjoy the new networked access.

The public had traditionally enjoyed liberal use rights in the libraries of statefunded colleges and universities. In most cases, anyone could walk into these libraries and use print collections. ${ }^{59}$ For libraries with a tradition of serving citizens living in the community, walk-in users constituted a small but significant user group. For example, high school students visited university libraries to do research, and local businesses used resources in academic libraries for research and development.

Early licenses that excluded walk-in users created a conflict with libraries' missions of serving the public and required renegotiation of license terms. From a SCOT perspective, definitions that excluded walk-in users were "nonworking models" of authorized users: that is, such definitions did not fit into libraries' conceptions of users. Walk-in users thus had to be separately negotiated into 
each of the hundreds of licenses a library might sign, increasing the work associated with licensing. But, as discussed above, the development of alternative norms of license negotiation within the library profession led to a liberalization of licensing language. Library organizations created principles, guidelines, and model licenses to encourage adoption of new definitions. ${ }^{60}$ For example, licensing principles recommended that any library patrons, regardless of their affiliation, should be included in the definition of authorized users. ${ }^{61}$ Interviews indicate that many libraries have institutional guidelines or checklists (for instance, include walk-in use) to guide negotiation and license review. Furthermore, some libraries have created their own definitions of "authorized user" and now insist that their definitions be used in any license agreement. ${ }^{62}$

Interviewees suggested that today most information providers are flexible in accommodating libraries' need to include walk-in users in their license agreements. Publishers may allow walkin users to retain good relationships with their library customers. They may also do so because the extent of walk-in use is small; moreover, walk-in use is becoming increasingly limited by the small number of publicly accessible computers. As computer security issues have grown, more library workstations require campus-based user IDs and passwords to $\log$ in. In many cases, walk-in users now need to ask a librarian to log them into a computer or run searches for them. The number of workstations completely open to the public to run an unmediated search is declining. This impediment arguably deters at least some use of e-resources by walk-in users.

Moreover, license language for some resources, especially those in science and engineering areas (such as chemistry, health sciences, and biotechnology), still excludes walk-in access. A few librarians interviewed stated that, in certain cases, they would prefer to cancel these sub- scriptions in hope of pressuring the publisher to change the license language, but they cannot cancel because the resources are important to the core researcher clientele of the library. While interview data and review of licensing listserv discussions of walk-in users suggest that libraries and publishers are close to sharing a single accepted conception of who walk-in users are and what they should be able to do, areas of disagreement and dissatisfaction continue to exist.

The question of whether alumni count as authorized users is similarly contentious. Some university and college libraries grant their alumni access to their paper resources (sometimes for a yearly fee that may constitute membership in a "Friends" organization). Although this group of users is often considered more privileged than walk-in users by libraries, they are typically not included in publisher definitions of authorized users and instead fall into the "walk-in" category. ${ }^{63}$ Moreover, most alumni users do not have campus IDs and therefore cannot use search workstations requiring log-ins. A survey of licensing practice showed that only 12 percent of U.S. academic libraries offered alumni access to their licensed resources, while about 30 percent offered access to a limited number of resources. ${ }^{64}$

Inclusion of alumni is problematic from several perspectives. While libraries would like to better serve alumni, today most e-resource pricing is based on estimated number of users, and including alumni in the pool of authorized users would greatly increase the price of the e-resource. ${ }^{65}$ Many publishers may be happy to allow alumni access at the increased price, but most libraries cannot afford it. Moreover, some information providers may worry that alumni access to e-resources will discourage business subscriptions or one-off article purchases. Alumni might be small-business owners who otherwise might subscribe or purchase articles. Given these complications, some librarians suggested it was "premature" to talk about expanded 
alumni access beyond walk-in use (such as permitting remote access), seeking instead to focus on other areas of potential agreement. ${ }^{66}$ Interview data suggest that the tensions surrounding alumni access remain in today's licensing practice.

\section{Physical Location of a "Site"}

Another area of change in conceptions of users was change in the definition of "site." In earlier licenses, conceptions of authorized users in license agreements were often embedded in definitions of the site. For example, licenses might set boundaries on the location of authorized users, thereby geographically restricting who could be an authorized user. Many early e-resource licenses defined where users of a product should be geographically located: a physical building or buildings, or a campus with clear geographic boundaries (for example, "5 miles surrounding the licensees address" or "all facilities of Licensee within one city"). ${ }^{67}$ Some licenses even assumed that access should take place on certain computers within a library. For example, a muchdebated early Science Online license agreement in 1998 limited access to computer workstations that "MUST be located in a library." 68

These early definitions of site were greatly complicated by new networking and remote access technologies. Before, customers could be identified by the geographical address to which a provider shipped a paper book or journal. But, in the mid-1990s, users began to demand remote access as Internet access grew more pervasive and "dialing in" to the campus library to access resources became possible. Older location-based licenses arguably did not permit remote access to e-resources.

Libraries and information providers initially differed in their conceptions of "site" and off-site or remote users as authorized users. In general, libraries sought definitions that made access more convenient, while providers initially resisted more expansive definitions of site. For libraries, it made sense to define a site by administrative attributes such as an entire university or college. ${ }^{69}$ Administrative definitions of site were especially important to academic libraries whose campuses were spread out over larger geographic areas. Some campuses had remote research parks or centers, and some campuses offered distance education programs with remote students and faculty. While definitions based on a single location might work well for smaller colleges and universities, interviews suggest that narrower definitions were nonworking for academic institutions with more complex geographies. Libraries thus pushed publishers to define sites administratively, regardless of location. ${ }^{70}$

Information providers initially resisted broader definitions of site. Some older licenses explicitly disallowed remote access, some had unclear definitions, and some providers charged extra fees for remote access. ${ }^{71}$ The older conceptions of "sites" likely stemmed from providers' long-standing experience with nonnetworked environments. Moreover, narrower conceptions of site made business sense to providers who sought to maximize subscription revenue. Defining sites as smaller geographical entities could force dispersed organizations to pay for multiple subscriptions for distinct access points regardless of whether the access points were administratively linked. ${ }^{72}$

Interview and secondary data suggest that, over time, most information providers changed definitions related to site and remote access to meet libraries' changing needs. But providers did not adopt the new technology and the new mental model at the same pace. Davis and Feather's comparison of pre-2000 and 2006 licenses shows that site definitions still heavily depend on geographical contiguity and that few licenses have changed the definition of site from single geographic locations to administrative entities. That being said, they found that most licenses allow remote access -65.7 percent explicitly allow it, and 34.3 percent remain silent on this 
issue. ${ }^{73}$ Providers' flexibility in permitting remote access has allowed libraries and publishers to continue to have different conceptions of site.

Providers did not rely on license language alone to define authorized users and sites; they supplemented and reinforced language-based restrictions with technological tools. The next section focuses on the technical elements of the social-technical mix that determine the contemporary "authorized user" of e-resources.

\section{Access Control Technologies as "Regimes of Alignment"}

License agreements between information providers and academic libraries defined users in contractual terms, but, over the past fifteen years, providers and libraries have worked together to develop and maintain systems of access control technologies (ACTs) that enable and enforce the conceptions of authorized users laid out in license agreements. ACTs, such as IP filtering and user authentication systems, have enforced license-based rules, "to [ensure] the right practices are facilitated, the wrong are inhibited." ${ }^{\prime 4}$ But, importantly, ACTs have also facilitated providers' acceptance of more expansive definitions of site (and thereby authorized users) by alleviating concerns about abuses. In this sense, ACTs are not just technological tools but rather "sociotechnical ensembles" because of the social rules embedded in their design and because they facilitate cooperation and shared understandings. ${ }^{75}$

ACTs can be seen as what Gillespie calls a regime of alignment, or a cooperatively managed system of policies, practices, and technologies controlling access or use of intellectual property. The term "alignment" points to the technology, policy, and managerial cooperation needed from all participants (that is, information providers and libraries) to make the system function. ${ }^{76}$ Similar to licenses, ACTs are negotiated and co-constructed by both parties and reflect the ever-changing relationship between them.
This section describes the coordination of technologies, policies, and managerial actions required for several ACTs commonly used for e-resources: IP filtering, proxy servers, and authentication and authorization systems.

\section{IP Filtering and Proxy Servers}

One important ACT that information providers and libraries maintain together is IP filtering technology. An IP address is assigned to a computer to enable it to be recognized as a network "node" and send and receive data. A simple method to ensure that only certain computers are accessing an e-resource is to "limit access to the IP range" of those computers on a licensee's campus. ${ }^{77}$ When libraries sign a license agreement with a provider, they regularly provide a list of IP addresses representing all campus computers.

In IP filtering, information providers check the IP address of an incoming request against the authorized list provided by the subscribing library. This filtering serves to police which computers can access the e-resource, enforcing the definition of authorized users by assuming that only authorized users use the computers in the authorized IP range. By the mid-1990s, IP filtering had become the predominant ACT because it is relatively secure and easy for information providers and libraries to cooperatively maintain. ${ }^{78}$ Moreover, the assumption that only authorized users are using computers in the approved IP range has been reinforced by the trend toward requiring a campus ID and password to $\log$ in to public computers.

The coordination between libraries and providers required for this system becomes more evident when problems occur. For example, the list of IP addresses provided by libraries to providers must be correct. Then, it must be regularly updated. Expansions or changes to the network may result in temporary inaccessibility for some IP addresses if libraries do not provide the correct IP addresses or if providers do not update their lists of IP addresses promptly. 
The proxy server represents another important codevelopment of an ACT regime of alignment. One limitation with IP filtering is that it does not allow for access by authorized users who are not on campus and whose computers therefore do not fall in the range of approved campus IP addresses. ${ }^{79}$ Demand for off-campus or remote access by users required a fix-libraries' conception of an authorized user included the assumption that one's location should not affect one's eligibility as a user. Therefore, libraries and publishers developed the proxy server solution to expand IP filtering to accommodate remote use. ${ }^{80}$ Proxy servers function by routing users' off-campus-based requests through a server that envelops the request within an IP address from the acceptable range. To an information provider, the request appears to have come from an on-campus computer. ${ }^{81}$ Or, as Agnew explains, "[a] proxy server with a valid IP address can request IP-range restricted resources on behalf of the library's (off campus) user." 82 But only authorized users can use the proxy server-today, in most cases, accessing a proxy server requires authentication through entry of a valid campus ID and password. Codevelopment of proxy server solutions have supported expanded conceptions of authorized users by facilitating remote use while also restricting use to those with a campus ID and password.

However, proxy technology was not always allowed by providers. Some initially hoped to force remote users into separate end-user-based service contracts. ${ }^{83}$ Providers also argued that remote users would increase support costs: If a library-based proxy server was out of service, users might complain to the vendor. ${ }^{84}$ Further, providers saw remote users as increasing the risk of unauthorized use. Finally, providers saw remote use and proxy servers as security risks: Improperly configured proxy servers became security loopholes. ${ }^{85}$ In one famous case from 2002, an unauthorized user employed an improperly configured proxy server to download large portions of JSTOR. ${ }^{86}$ Kevin Guthrie, president of JSTOR, in explaining the incident, expressed concerns shared by many information providers: "Anybody on a campus can set up a Web server and can either accidentally or for some other reason open up some other proxies." ${ }^{187} \mathrm{As}$ demand for Internet and networked access to information resources rose in the late 1990s, information providers conceded the importance of remote access and gradually accepted the proxy server solution without charging extra fees. ${ }^{88}$ But because of the potential security threats, most licenses still require that libraries use a central proxy server maintained by campus IT to reduce risks of improper configuration. ${ }^{89}$

\section{Authentication and Authorization}

Another common ACT maintained jointly by libraries and information providers is a set of tools and methods known as authentication and authorization services. These services are not merely technical tools but also are social arrangements described as "an arrangement between a community of individuals and an administrative organization in a position to verify their identities." ${ }^{\prime 90}$ This definition highlights the social requirements or "arrangements" underlying the technical service. Moreover, common authentication and authorization methods depend on standards created through social standards-making processes with the involvement of library and information provider communities. ${ }^{91}$

In the authentication process, users must prove to the system that they have the right to use stored identities through entrance of "credentials" such as usernames, identification numbers, and passwords. ${ }^{92}$ Authorization processes happen after authentication: authorization establishes the functions that the user is allowed to perform or the permissions or rights a user enjoys based on the stored identity. ${ }^{93}$

Authentication and authorization for e-resources also has a history. Prior to the 
development of centralized authentication systems, use of institutional usernames and passwords or "institutional authentication" was common. In institutional authentication, one username and one password were given to each subscribing institution. The username and password were distributed to users by librarians. Passwords were periodically changed and then redistributed to users. One benefit of this method was that it allowed users who had received the usernames and passwords to access the resources regardless of location. However, widely distributed institutional usernames and passwords were easy to disseminate and therefore not secure.

To expand access outside the library but keep institutional passwords secret, libraries created secure passwordprotected Web pages that listed links to e-resources with their respective log-in information. Passwords for the secure Web pages were only given to patrons after their affiliations were authenticated by librarians. ${ }^{94}$

Another ACT popular with some providers has been to require users to set up personal accounts with usernames and passwords for that provider's particular e-resource. This method gives providers better control over who is using their products, but it is inconvenient for users. While this method was initially more widely used, with the growing number of e-resources in collections, it became increasingly untenable, and libraries began to push information providers to use a different method. The method is still in use by a small number of providers today. A 2008 survey suggested that approximately 25.6 percent of academic libraries' content still requires user passwords or other means of individual identification. ${ }^{95}$ While this method is inconvenient for users, libraries may accept it because of the importance of the resources for their students and faculty, and possibly because of some libraries' past inability to properly maintain an alternative IPproxy solution.
Within authentication, the question of what user ID to employ has shifted over time. Discussions about what credential should be used were abundant on the LibLicense list in the late 1990s. Most libraries initially used library-specific patron IDs and passwords to authenticate users. Some librarians even considered using Social Security numbers, which created much concern about privacy. ${ }^{96}$ Libraryspecific or "patron" IDs were widely used because libraries already had in-house databases of patron IDs developed to control circulation of paper items. But, toward the end of the 1990s, as colleges and universities began to create campuslevel ID systems, many libraries switched to the campus ID/password credential.

Today, most authentication and authorization services occur through centralized campus authentication services. These services store the "identities" or data representing users, such as campus ID numbers, addresses, and other personal information..$^{97}$ Authorization is often established by group membership. The authorization service clusters identities into group assignments that denote certain rights. For example, when a user logs in, her username/password combination identifies her as Susan Jones, a graduate student in the Pharmacy School (identity). In most cases, her belonging to the broad "student" group grants her rights to all the campus e-resources. In some cases, discussed below in the Shibboleth example, more refined group memberships (like Pharmacy School student) may be used to automatically grant a more refined set of rights.

Authorization and authentication systems also now control use of public computer terminals in campus libraries. As noted earlier, security concerns have led most campuses to require authentication via the campus authentication service to use "public" computer terminals. This has had the side effect of increasing some information providers' willingness to allow walk-in use. Some interviewees suggested that today most information 
providers agree to include walk-in users because the extent of walk-in use is often limited by the small number of truly publicly accessible computers or the need to ask a librarian for assistance.

Authorization and authentication systems rely on cooperation because most providers do not perform authentication and authorization themselves but rather trust the authentication systems set up by universities (exceptions include those vendors that require individual user accounts). Providers trust campuses to keep their identity data up to date, promptly reflecting changes to the status of a user (for instance, graduation). Moreover, providers trust campuses to only include individuals who are bona fide members of the campus in the database.

Combined with proxy servers, authentication and authorization systems expand working definitions of authorized users to include all remote users who can gain authentication through entry of campus ID and password information. The interworking of the proxy and authentication systems ensures that remote users' requests appear to fall in the IP range required by providers' IP filtering mechanisms. If a remote user's ID and password match information stored in the authentication system, her requests thereafter appear to come from an authorized IP address, as explained in the previous section..$^{98}$

While libraries and providers have largely agreed upon and cooperated in the creation and maintenance of the IP range/proxy/authentication security configuration, some debates remain. For example, a few journal publishers have been unwilling to depend on a university's authentication system to validate access to their journals, so they require additional personal registration..$^{99}$ As a next step, some information providers wish to further limit access by user roles, such as enrollment in certain classes or students in certain departments/schools. ${ }^{100}$ These limitations cannot be easily supported by the contemporary IP range/proxy/authen- tication system but could be facilitated by newer systems like Shibboleth.

The Shibboleth system, a relatively new authorization protocol, can support finer-grained group-based authorizations and access controls. ${ }^{101}$ It employs user attributes such as status, department, or course enrollment rather than simple campus affiliation. When a user initiates a request to an e-resource, Shibboleth sends those attributes required by the information provider. The provider then grants access based on these individual attributes. ${ }^{102}$ Shibboleth can allow for finer-grained role-based access control by making it possible to limit access by major or current course enrollment. ${ }^{103}$

The ability to automatically restrict access to smaller groups opens the door for new pricing models. ${ }^{104}$ For e-resources whose prices are based on the number of users, finer-grained access control might lead to lower prices. But since Shibboleth is new, there is yet no evidence to show how it will affect existing pricing, access, and licensing practices.

This new finer-grained access restriction could increase tensions between libraries' mission to serve a broad public and libraries' need to control costs. Shibboleth could shift the norm of access control away from simple institutional affiliation toward access control based on narrow affiliations such as major or class registration. At the same time, Shibboleth arguably could reduce the costs of providing access to expensive resources by limiting access to a smaller set of users. Also, Shibboleth could make it technically easier to create a business model for selling access to walk-in users and alumni for a special rate. However, it is unclear whether libraries will tolerate the finer-grained access controls in return for price reductions. Denying access to all campus affiliates runs against the library mantra of expanding access. Moreover, if fine-grained access control becomes prevalent, noncore academic library users like walk-in users and alumni will likely be further marginalized in the face of 
needs to reduce costs. ${ }^{105}$ The implications of Shibboleth are yet to be seen, but the future implementation will rely on the cooperation of both libraries and providers.

From a SCOT perspective, remote access has stabilized. Its interpretive flexibility - or the differences in perception between libraries and providers - has decreased. The development of IP filtering and authorization-based proxy access has facilitated shared definitions of authorized user and site. These ACT regimes of alignment are maintained through cooperation of libraries and providers and reflect a combination of their values and concerns. The successful deployment of ACTs relies on the technological, policy, and managerial coordination or "alignment" of both groups. But this closure of interpretive flexibility is only temporary because new access control technologies, such as Shibboleth, are under development and will likely reopen the debates between libraries and informaton providers about who should be an authorized user of an e-resource.

\section{Conclusion}

Many technology enthusiasts hoped that digital information, easily available through the Internet, would bring more equality and freedom. ${ }^{106}$ One of the characteristics of the "information society" or "knowledge society" that many scholars have advocated is the dissemination of knowledge to support the emancipation of individuals and improvement of every aspect of life. ${ }^{107}$ Academic libraries have seen themselves as key facilitators of increased access to information for both core constituencies and the general public. This paper's analyses moderates this enthusiasm by demonstrating how questions of access, particularly for noncore patrons such as the general public and alumni, have become more complicated.

This paper traced changes in the conception of "authorized users" in both licenses and access control technologies employed by information providers and libraries to mediate access to e-resources.
It employed three theoretical conceptsinterpretive flexibility, boundary objects, and regimes of alignment-to explain the observed changes in conceptions of authorized users of licensed e-resources from the mid-1990s to the present.

The currently popular means of mediating access (that is, common license terms, commonly employed access control technologies) within state-funded college and university libraries arguably facilitates greater access to more material for core library patrons than they did under the historical paper environment. Researchers and students enjoy increasingly convenient and timely services. But all the convenient features came with a price for the noncore patrons of the library: the access rights of the public (including alumni) are arguably weaker. Many libraries have preserved the right, after contention and negotiation, for the general public to walk into a public academic institution and access many licensed resources in license terms. Further, one could argue that walk-in users, in many cases, have access to a wider collection of resources than existed in the paper environment. But walk-in access typically now requires asking a librarian for guest permission to $\log$ in to a library workstation. Further, some resources simply do not allow walk-in use. The public is increasingly becoming an information have-not in the licensed information realm, and academic libraries cannot serve the general public as well as they might like. The circumstances have also worsened due to increasing cancellation of print journal subscriptions (fully accessible to walk-in users) in favor of electronic-only subscriptions (requiring a log-in). ${ }^{108}$ Therefore, while walk-in use may be formally included in license definitions of authorized users, the increased requirements for log-ins on public workstations to some extent weaken the license-based inclusion.

The question of to what degree the shift to e-resources and the current ACT regime of alignments disadvantage public 
users of academic libraries merits further research. Users of published research materials consist not only of professional researchers, but also of "historians and philosophers, editors, consultants, students and educators, journalists, consumer advocacy groups, government regulators and policy makers, and members of the legal community, as well as any member of that diverse group we refer to as the 'general reading public.'" 109 Academic libraries are invaluable repositories to people who take interest in scientific, technological, or social inquiry, and in a print-based environment, the "general reading public" went to academic libraries to access advanced knowledge. Under the current combination of authorized user definitions and ACT implementation, much of the digitized scholarly information may be inaccessible to the "general reading public" without mediation by a librarian (that is to say, asking for a guest log-in). Research is needed to assess to what extent workstation logins deter public/alumni use of resources; however, if we assume that the log-in requirement deters at least some public users, then access to research is arguably declining in this "knowledge society."

Concerns about the reading rights of the general public are one of the motivations of the "open access movement."110 The open access movement emphasizes the importance of scholarly information as a public good rather than "a capitalized commodity and economic driver." 111 Open access has potential to address the erosion of public reading rights, making information available for free by shifting the cost of publishing to authors or granting agencies or by encouraging the deposit of preprints in open repositories. It is unclear at this point, however, how successful the open access movement will be in expanding the amount of electronic material freely available to the public. Regardless of whether the open access movement will eventually bring changes to the concept of authorized users, the current licensing and access models are not going to be replaced any time soon.

Of course, it is not only a matter of social value, but also of business. To information providers, a wider authorized user population could weaken revenue from other markets such as small businesses and occasional pay-per-view readers. If businesses choose not to buy information products and instead rely on walk-in use at their local academic libraries (or hire students to do research in the library on their behalf), the libraries might reasonably be charged higher prices for these extra users. Libraries, however, receive no funding from public users for this cost. As a result, the economic phenomenon of the "tragedy of commons" could be exacerbated because libraries as "information commons" find it difficult to sustain this access model with ever-decreasing budgets and increasing prices. ${ }^{12}$ Some argue that the ideal of the widest possible access is unrealistic, even if desired, under the current scholarly publishing model. As library collections come to be dominated by e-resources, determining who is an authorized user of academic library collections becomes increasingly significant. And, in an era of constricting resources, most academic institutions cannot afford to pay more in license fees for increased access.

\section{Notes}

1. Henry Jenkins and David Thorborn, "Introduction: The Digital Revolution, the Information Citizen, and the Culture of Democracy," in Democracy and New Media, eds. H. Jenkins and D. Thorborn (Cambridge, Mass.: MIT Press, 2003), 1-20.

2. Wiebe E. Bijker and John Law, Shaping Technology/ Building Society: Studies in Sociotechnical Change (Cambridge, Mass.: MIT Press, 1994), 10.

3. Langdon Winner, The Whale and the Reactor: A Search for Limits in an Age of High Technology (Chicago: University of Chicago Press, 1986); Tarleton Gillespie, Wired Shut: Copyright and the Shape of Digital Culture (Cambridge, Mass.: MIT Press, 2007), 102. 


\section{Social Construction of Authorized Users in the Digital Age 563}

4. Wiebe E. Bijker, Of Bicycles, Bakelites, and Bulbs: Toward a Theory of Sociotechnical Change (Cambridge, Mass.: MIT Press, 1995).

5. Susan L. Star, "The Structure of Ill-structured Solutions: Boundary Objects and Heterogeneous Distributed Problem Solving," in Distributed Artificial Intelligence, eds. L. Gasser and M.N. Huhns, vol. 2 (London: Pitman, 1989), 37-54.

6. Gillespie, Wired Shut, 102-04.

7. Royce A. Singleton, Jr. and Bruce C. Straits, Approaches to Social Research, 3rd ed. (New York: Oxford University Press, 1999), 376.

8. Ideally, primary sources would include license agreements between libraries and information providers throughout the years. However, because of the difficulty of obtaining original license agreements from individual libraries, standard license agreements (from LibLicense, http://www.library.yale.edu/ llicense/publishers.shtml) and a selection of contracts compiled by Peter Marx in the 1990s were studied instead. Since these standard licenses only show the most recent terms and often change with different licensees, they therefore do not indicate any changing processes and they only serve as a background reference in this study. Contracts in the Information Industry II, ed. Peter Marx (Washington, D.C.: Information Industry Association, 1990); Contracts in the Information Industry III, ed. Peter Marx (Washington, D.C.: Information Industry Association, 1995).

9. LibLicense. Liblicense-L list archives available at www.library.yale.edu/ 1license/ ListArchives/. [Accessed 30 October 2009].

10. The main sources were the National Federation of Abstracting and Information Services (NFAIS) newsletters and the newsletter of Association of Information and Dissemination Centers (ASIDIC), and relevant reports published by the Information Industry Association (IIA), Serials Librarian, Journal of Electronic Publishing, Publishing Research Quarterly, Database, Online, and Journal of Scholarly Publishing were also browsed. Conference proceedings of North American Serials Interest Group (NASIG) published in Serials Librarian are especially useful for learning the background of licensing and licensing practice in the library field.

11. The interviews were conducted for a separate but related study, "A Study on Digital Resources Licensing," which included numerous semistructured questions related to licensing practice. In many cases, the issue of authorized users and changes in the definition of authorized users was brought up by the participants in response to open-ended questions. For example, when asked about the challenges of license negotiation or guidelines for negotiation, many participants talked about the definition of users as one of the issues. Such responses were helpful to this study and used as data.

12. The eighteen participants were recruited from thirteen academic libraries, two publishers/vendors, and one library consortium. Of the thirteen academic libraries, four were private colleges or universities and nine were public universities. Four libraries were at campuses with smaller student enrollments $(1,000-10,000)$, four were at campuses with medium enrollments $(10,001-20,000)$, and five were at campuses with large student enrollments $(20,001-54,000)$. Four libraries had smaller number of FTE staff (30-60), four had medium number of staff (61-150), and five had large number of staff (151-600). Five libraries had smaller annual expenditures $(\$ 1 \mathrm{M}-\$ 5 \mathrm{M})$, three had medium annual expenditures $(\$ 5 \mathrm{M}-\$ 15 \mathrm{M})$, and five had large annual expenditures $(\$ 15 \mathrm{M}-\$ 45 \mathrm{M})$. The numbers are based on The Academic Library Survey (ALS) Public Use Data File: Fiscal Year 2006 published by Institute of Education Sciences in 2008 (http://nces. ed.gov/surveys/libraries/aca_data.asp). Numbers are rounded to protect the confidentiality of interviewees.

13. Norman K. Denzin, The Research Act: A Theoretical Introduction to Sociological Methods, 2nd ed. (New York: McGraw-Hill, 1978), 291; Laurel Richardson, Fields of Play: Constructing an Academic Life (New Brunswick, N.J.: Rutgers University Press, 1997), 8.

14. Todd D. Jick, "Mixing Qualitative and Quantitative Methods: Triangulation in Action," Administrative Science Quarter 24, no. 4 (1979): 602-11.

15. Richardson, Fields of Play, 255; Laurel Richardson and Elizabeth Adams St. Pierre, “Writing: A Method of Inquiry," in Sage Handbook of Qualitative Research, eds. N.K. Denzin and Y.S. Lincoln, 3rd ed. (Thousand Oaks, Calif.: Sage, 2004), 959-78.

16. Laura L. Ellingson, Engaging Crystallization in Qualitative Research: An Introduction (Thousand Oaks, Calif.: Sage, 2008), 4.

17. Bijker, Of Bicycles, Bakelites, and Bulbs.

18. Elmer D. Johnson, A History of Libraries in the Western World (New York: Scarecrow Press, 1965).

19. Ann Okerson, "Whose Work Is It Anyway? Perspectives on the Stakeholders and the Stakes in the Current Copyright Scene," Serials Librarian 28, no. 1/2 (1996): 81.

20. Allen B. Veaner, Academic Librarianship in a Transformational Age: Programs, Politics, and Personnel (Boston: G.K. Hall \& Co., 1990), 3-4. 
21. Ibid., 14.

22. Richard C. Quick, "Community Use: Dealers Choice," College and Research Libraries 28, no. 3 (1967): $185-88$.

23. Corol Tenopir and Donald W. King, "Designing Electronic Journals with 30 Years of Lessons from Print," Journal of Electronic Publishing 4, no. 2 (1998). Available online at http://hdl. handle.net/2027/spo.3336451.0004.202. [Accessed 20 May 2009].

24. Trisha Davis, “License Agreements in Lieu of Copyright: Are We Signing Away Our Rights?" Library Acquisitions: Practice \& Theory 21, no. 1 (1997): 21; Ann Okerson, “What Academic Libraries Need in Electronic Content Licenses: Presentation to the STM Library Relations Committee, STM Annual General Meeting, October 1, 1996," Serials Review 22, no. 4 (1996): 65-69.

25. Karen S. Silverman, "CD-ROM in Libraries: Access, Trends and Challenges," Serials Librarian 17, no. 3/4 (1990): 49-62.

26. Charles P. Bourne and Trudi Bellardo Hahn, A History of Online Information Services: 1963-1976 (Cambridge, Mass.: MIT Press, 2003); "PyscLIT on SilverPlatter," in Contracts in the Information Industry II, ed. Peter Marx (Washington, D.C.: Information Industry Association, 1990), 112; "DIALOG Information Services, Inc. Database Supplier Terms and Conditions," in Contracts in the Information Industry II, ed. Peter Marx (Washington, D.C.: Information Industry Association, 1990), 187; "Mead Data Central, Inc. Lexis/Nexis Subscription Agreement," in Contracts in the Information Industry II, ed. Peter Marx (Washington, D.C.: Information Industry Association, 1990), 205.

27. "DIALOG OnDisc Order Form and License Agreement," in Contracts in the Information Industry II, ed. P. Marx (Washington, D.C.: Information Industry Association, 1990), 99.

28. Eamon T. Fennessy, “Web Security for Secondary Publishers," NFAIS Newsletter 39, no. 8 (1997): 97-101; Norman Wiseman, "Implementing a National Access Management System for Electronic Services: Technology Alone Is Not Enough," D-Lib Magazine 4 (Mar. 1998), available online at www.dlib.org/dlib/march98/wiseman/03wiseman.html [Accessed 20 May 2009]; Vince Yannuzzi, "The E-content Revolution: Opportunities and Pitfalls," ASIDIC Newsletter 75 (1998): 9-10.

29. Joseph L. Ebersole, Protecting Intellectual Property Rights on the Information Superhighways (Washington, D.C: Information Industry Association, 1994); Joseph L. Ebersole, "Does Copyright Protect Your Database? Unlikely!" NFAIS Newsletter 40, no. 2 (1998): 17-21; Fennessy, "Web Security for Secondary Publishers," 97-101; Kurt N. Molholm, “Defending the Internet," NFAIS Newsletter 39, no. 8 (1997): 97, 99, 101-02.

30. Nancy L. Buchanan, "Navigating the Electronic River: Electronic Product Licensing and Contracts," Serials Librarian 30, no. 3/4 (1997): 171-82; Trisha Davis, "License Agreements in Lieu of Copyright;" interviews with informants.

31. Carol Tenopir and Donald W. King, Towards Electronic Journals: Realities for Scientists, Libraries, and Publishers (Washington D.C.: Special Libraries Association, 2000), 339-41; M. Farjoun, "The Dialectics of Institutional Development in Emerging and Turbulent Fields: The History of Pricing Conventions in the On-line Database Industry," Academy of Management Journal 45, no. 5 (2002), 848-74; Ron Akie, "Ron Akie and the Future of SilverPlatter Information," NFAIS Newsletter 40, no. 5 (1998): 71; Morris Goldstein, "Site Licensing and Multiple Media Site Loads," ASIDIC Newsletter 60 (1990): 4.

32. Llius Anglada and Nuria Comellas, "What's Fair? Pricing Models in the Electronic Era," Library Management 23, no. 4/5 (2002): 227-33; Dennis Auld, "Introduction," ASIDIC Newsletter 77 (1999): 4-6; Tenopir and King, "Designing Electronic Journals."

33. Carl Shapiro and Hal R. Varian, Information Rules: A Strategic Guide to the Network Economy (Boston: Harvard Business School Press, 1999); Kristin R. Eschenfelder, Anuj C. Desai, and Greg Downey, "The Pre-Internet Downloading Controversy: Bibliographic Citations and the Evolution of Use Rights for Digital Works," manuscript under review, University of WisconsinMadison School of Library and Information Studies (2009).

34. Ev Brenner, “The End User Is Still a Loser," NFAIS Newsletter 42, no. 9 (2000): 138-39; Sheila Waters, "Budgeting for Document Delivery," NFAIS Newsletter 38, no. 10 (1996): 142; Wicks, "The 1995 Yearbook," NFAIS Newsletter 38, no. 1 (1996): 4-9.

35. Harry Collier, "Heresies for an Information Meeting," ASIDIC Newsletter 62 (1991): 13-15. Many publishers were especially concerned about the individual end-user market. Because of the technology and price barrier before the 1990s, the individual customers market was relatively untouched. For evidence, see Collier, "Heresies for an Information Meeting." The introduction of CD-ROMs expanded the academic market and helped educate end users on searching. For discussion, see Christopher Pooley, "Licensing CD-ROMs to Library Networks," ASIDIC Newsletter 60 (1990): 4-5; Ron Rietdyk, “A CD-ROM Producer's View," ASIDIC Newsletter 62 (1991): 10-11. As Internet-based distribution became more of a reality, end users became accustomed to searching, and the concept of "E-Commerce" was introduced, delivering full-text articles to 


\section{Social Construction of Authorized Users in the Digital Age 565}

users' desktops became technically viable.

36. Karen Hunter, "ScienceDirect," in E-serials: Publishers, Libraries, Users, and Standards, ed. W. Jones, 2nd ed. (Binghamton, N.Y.: The Haworth Information Press, 2002), 21.

37. Colin Day, "The Economics of Electronic Publishing: Some Preliminary Thoughts," in Gateways, Gatekeepers, and Roles in the Information Omniverse: Proceedings of the Third Symposium: November 13-15, 1993, the Washington Vista Hotel, Washington, D.C., eds. A. Okerson and D. Mogge (Washington, D.C.: Office of Scientific and Academic Publishing, Association of Research Libraries, 1994); Janet H. Fisher, "The True Costs of an Electronic Journal," Serials Review 21, no. 1 (1995): 88-90; Malco Getz, "Electronic Publishing: An Economic View," Serials Review 18, no. 1/2 (1992): 25-31; Tony Stankus, "The Key Trends Emerging in the First Decade of Electronic Journals in the Sciences," in Electronic Expectations: Science Journals on the Web (New York: Haworth Information Press, 1999), 5-20.

38. Information providers' concern about print subscription: Suzan A. Brown, "Pricing Options Serve Diverse User Needs," NFAIS Newsletter 39, no. 6 (1997): 74; M.L. Neufeld, "Changing Relationships in the Information-Transfer Chain," NFAIS Newsletter 40, no. 3 (1998): 38; Debra Brown-Sprull, "PAIS Prepares for the 21st Century," NFAIS Newsletter 40, no. 10 (1998): 159. Decrease in scholar/scientists personal subscriptions: Carol Tenopir, Donald W. King, Peter Boyce, Matt Grayson, Yan Zhang, and Mercy Ebuen, "Patterns of Journal Use by Scientists through Three Evolutionary Phases," D-Lib Magazine 9, no. 5 (2003); Carol Tenopir and Donald W. King, "Lessons for the Future of Journals," Nature 413 (18 Oct 2001): 672-74.

39. Peter Adams, "Technology in Publishing: A Century of Progress," in Scholarly Publishing: Books, Journals, Publishers, and Libraries in the Twentieth Century, eds. R.E. Abel and L.W. Newlin, (New York: John Wiley \& Sons, 2002), 29-45; Sharon Berglund, "Full-text Searching on Major Supermarket Systems: Dialog, Data-Star, and Nexis," Database Magazine 16, no. 5 (1993): 32.

40. James Drier, "Evolution of Intranet Distribution to Professional Markets," ASIDIC Newsletter 76 (1998): 16-17; Morris Goldstein, "Changing Paradigms in Information Marketing," ASIDIC Newsletter 67 (1993): 12-13.

41. This statement is supported by interview data gathered during this research.

42. John Cox, "The Role of the Paper-based Journal in an Era of Electronic Information," Serials Librarian 30, no. 3/4 (1997): 41-53; Fred S. Rosenau and Leslie R. Chase, So You Want to Be a Profitable Database Publisher (Washington D.C.: Information Industry Association, 1983); Peggy A. Miller and Arthur J. Levine, The Information Executive's Guide to Intellectual Property Rights (Washington D.C.: Information Industry Association, 1985); Marx, Contracts in the Information Industry II.

43. Star, "The Structure of Ill-structured Solutions," 46.

44. The contracts were also called leases, service agreements, subscriber agreements, subscription agreements, or license agreements.

45. Ann Okerson, "The Transition to Electronic Content Licensing: The Institutional Context in 1997," in Technology and Scholarly Communication. eds. R. Ekman and R. Quandt (Berkeley: University of California Press, 1999), 53-70; Edward A. Warro, "What Have We Been Signing? A Look at Database Licensing Agreements," Library Administration and Management 8 (Summer 1994): 173-77.

46. Laura N. Gasaway, "Copyright in the Electronic Era," Serials Librarian 24, no. 3 (1994): 153-62; Warro, "What Have We Been Signing?" 173-77.

47. Okerson, "The Transition to Electronic Content Licensing"; Warro, "What Have We Been Signing?"

48. Bill Kara, Ann Caputo, Trisha Davis, and Nancy Gibbs, "Negotiating Contracts for Electronic Resources," Serials Librarian 25, no. 3/4 (Mar. 1995): 269-75.

49. Okerson, "The Transition to Electronic Content Licensing"; Roger C. Schonfeld, JSTOR: A History (Princeton, N.J.: Princeton University Press, 2003).

50. Okerson, "The Transition to Electronic Content Licensing," 60.

51. For example, Rick Anderson, Buying and Contracting for Resources and Services (New York: Neal-Schuman Publishers, 2004); Arlene Bielefield and Lawrence Cheeseman, Interpreting and Negotiating Licensing Agreements: A Guidebook for the Library, Rresearch, and Teaching Professions (New York: Neal-Schuman Publishers, 1999); Fiona Durrant, Negotiating Licenses for Digital Resources (London: Facet Publishing, 2006); Lesley L. Harris, Licensing Digital Content: A Practical Guide for Librarians (Chicago: American Library Association, 2002); Gretchen M. Hoffmann, Copyright in Cyberspace 2: Questions and Answers for Librarians (New York: Neal-Schuman Publishers, 2005); Robert Ubell, Negotiating Networked Information Contracts and Licenses (New York: Robert Ubell Associates, 1994).

52. Buchanan, "Navigating the Electronic River."

53. Kara, Caputo, Davis, and Gibbs, "Negotiating Contracts for Electronic Resources." 
54. Davis, "License Agreements in Lieu of Copyright."

55. Hunter, "ScienceDirect," 21.

56. Buchanan, "Navigating the Electronic River," 176.

57. Anita Lowry, "Landlords and Tenants: Who Owns Information, Who Pays for It, and How?" Serials Librarian 23, no. 3/4 (1993): 61-71.

58. Lowry, "Landlords and Tenants," 67.

59. Special collections, sensitive materials, or other subsets of material might have had some restrictions on access or use.

60. Prominent examples include model licenses and principles created by the Council on Library and Information Resources (CLIR) and the Digital Library Federation (DLF), the Association of Research Libraries (ARL), and International Federation of Library Association (IFLA).

61. CLIR/DLF Model License, May 2008, available online at www.library.yale.edu/ llicense/ standlicagree.pdf [Accessed 1 December 2008]; Association of Research Libraries, Principles for Licensing Electronic Resources, July 15, 1997, available online at www.arl.org/sc/marketplace/ license/licprinciples.shtml [Accessed 1 December 2008]; IFLA, Licensing Principles (2001), May 1, 2001, available online at http://archive.ifla.org/V/ebpb/copy.htm [Accessed 1 December 2008].

62. For example, MIT had the following definition: "Authorized Users shall consist of: 1) persons officially registered as full or part-time students of MIS including those participating in distance education programs; its faculty (including some retired faculty) and other members of the teaching staff; administrators; employed staff; 2) authorized affiliates (including, e.g., some House Masters and Chaplains; the President's spouse; and Members of the MIT Corporation); affiliated or visiting scholars or researchers; and consultants under contract with MIT; 3 ) other individual authorized users sponsored by senior MIT faculty or staff with guest accounts to complete academic or administrative work; and 4) patrons physically present in the MIT Libraries." Ellen F. Duranceau, "An Eclipse of the Sun: Acquisitions in the Digital Era," in E-serials: Publishers, Libraries, Users, and Standards, ed. W. Jones, 2nd ed. (Binghamton, N.Y.: The Haworth Information Press, 2002), 60.

63. Edward C. Heintz, "Alumni, Overdue Books, and Interlibrary Loan," College and Research Libraries 28, no. 3 (1967): 189-91; Ann Okerson, "Alumni Access, More," e-mail to Liblicense-L mailing list, February 7, 1997. Available online at www.library.yale.edu/ llicense/ListArchives/9702/ msg00028.html. [Accessed 12 November 2008].

64. Primary Research Group, The Survey of Library Database Licensing Practices (New York: Primary Research Group Inc, 2008). The sample size of the survey was small; therefore, its generalizability is dubious. In addition, it is not clear from the survey results how the rights are defined in the license agreements. However, the survey does show that alumni access is happening in at least some institutions.

65. David Mirchin, "Authorized Users Questions," e-mail to Liblicense-L mailing list, Aug. 22, 1997. Available online at www.library.yale.edu/ llicense/ListArchives/9709/msg00031.html. [Accessed 12 November 2008].

66. Lowry, "Landlords and Tenants"; Chris Ferguson, "Remote Alumni Access to Electronic Resources," e-mail to Liblicense-L mailing list, Feb. 7, 1997, available online at www.library.yale. edu/ llicense/ListArchives/9702/msg00011.html [Accessed 12 November 2008]; Ann Okerson, "Alumni Access - A Memo," e-mail to Liblicense-L mailing list, Feb. 7, 1997, available online at www.library.yale.edu/ llicense/ListArchives/9702/msg00025.html [Accessed 12 November 2008].

67. Interview quotation; Buchanan, "Navigating the Electronic River," 174.

68. William S. Monroe, "Science Online," e-mail to Liblicense-L mailing list, Jan.15, 1998. Available online at www.library.yale.edu/ 1license/ListArchives/9801/msg00015.html. [Accessed 12 November 2008].

69. Janet H. Fisher, "Electronic Journal Update: CJTCS," Serials Librarian 28, no. 1/2 (1996): $135-38$

70. Trisha Davis and Celeste Feather. "The Evolution of License Content," in Electronic Resource Management in Libraries: Research and Practice, eds. H. Yu and S. Breivold (Hershey, Pa.: Information Science Reference, 2008), 125-26.

71. Buchanan, "Navigating the Electronic River," 178.

72. David Goodman, "Re: American Society for Microbiology," e-mail to LibLicense-L Mailing list, Nov. 24, 1998. Available online at www.library.yale.edu/ llicense/ListArchives/9811/msg00022. html. [Accessed 12 November 2008].

73. Davis and Feather, "The Evolution of License Content," 126, 141.

74. Gillespie, Wired Shut, 6.

75. Bijker, Of Bicycles, Bakelites, and Bulbs, 12; Steve Woolgar, "Technologies as Cultural Artefacts," in Information and Communication Technologies: Visions and Realities, ed. W.H. Dutton (New York: Oxford University Press, 1996), 87-102; Langdon Winner, Autonomous Technology (Cambridge, Mass.: MIT Press, 1977). 


\section{Social Construction of Authorized Users in the Digital Age 567}

76. Gillespie, Wired Shut, 102.

77. Grace Agnew, Digital Rights Management: A Librarian's Guide to Technology and Practice (Oxford: Chandos Publishing, 2008), 186.

78. Dennis Krieb, "You Can't Get There from Here: Issues in Remote Access to Electronic Journals for a Health Sciences Library," Issues in Science \& Technology Librarianship 22 (Spring 1999), available online at www.istl.org/99-spring/article3.html [Accessed 20 May 2009]. This method does have the risk of IP spoofing, which might be done by hackers for different purposes. In this case, a hacker might falsify his or her IP to pretend to be an authorized user. However, getting responses back to a spoofed IP address is much harder than authorizing the false address, and there are other measures to prevent such activities. Therefore, IP spoofing is only a minor concern in IP filtering. For discussion, see Clifford Lynch, A White Paper on Authentication and Access Management Issues in Cross-organizational Use of Networked Information Resources, 1998. Available online at www.cni.org/projects/authentication/authentication-wp.html.

79. Margaret A. Rioux, "Hunting and Gathering in Cyberspace: Finding and Selecting Web Resources for the Library's Virtual Collection," Serials Librarian 30, no. 3/4 (1997): 134; Mark Bide and Trevor Hing, User Identification and Authentication: A Brief Introduction (London: Book Industry Communication and EDItEUR, 1998), 3-4, available online at www.egov.vic.gov.au/pdfs/userid. pdf [Accessed 1 December 2008]; Agnew, Digital Rights Management, 187.

80. Ibid, 133-34.

81. A proxy server, also called a Web cache, is a network server that satisfies HTTP requests on the behalf on a client. Users configure their browsers so that all of their HTTP requests are first directed to the proxy server. For details, see James F. Kurose and Keith W. Ross, "Computer Networking: A Top-down Approach Featuring the Internet" (Boston: Addison-Wesley, 2001). With libraries setting up proxy servers that tunneled users' requests, users were able to access the resources remotely when their IP addresses fell out of the authorized IP ranges. A user's queries came from the proxy server, which made it appear that they came from an authorized IP address. With some products, such as EZproxy, users did not even need to configure their browsers. For further discussion, see Mark Cain, "Cybertheft, Network Security, and the Library Without Walls," Journal of Academic Librarianship 29, no. 4 (2003): 245-48.

82. Agnew, Digital Rights Management, 187.

83. Waters, "Budgeting for Document Delivery," 142.

84. Lynch, White Paper on Authentication and Access Management Issues.

85. Dan Carnevale, "Security Lapses Permit Theft from Database of Scholarly Journals," The Chronicle of Higher Education 49, no. 21 (2003): A29; Ken Robinson, "Re: Simultaneous User Flavors," e-mail to Liblicense-L mailing list, Feb. 5, 1997, available online at www.library.yale. edu/ llicense/ListArchives/9702/msg00050.html [Accessed 20 May 2009].

86. JSTOR, "Open Proxy Servers: Gateways to Unauthorized Use of Licensed Resources," JSTORNews 3, no. 6 (December 2002), http://fsearch-sandbox.jstor.org/news/2002.12/open-proxy. html. [Accessed 13 August, 2008.]

87. Carnevale, "Security Lapses Permit Theft," A29.

88. Becky Clarke and R.R. Bowker. "Purchasing Trends in Academic and Public Libraries," ASIDIC Newsletter 75 (Spring 1998): 16-17; Buchanan, "Navigating the Electronic River," 178.

89. Cain, "Cybertheft, Network Security, and the Library Without Walls," 257.

90. David Millman, "Authentication and Authorization," in Encyclopedia of Library and Information Science, ed. M. Drake, 2nd ed. (New York: Marcel Dekker, 2003), 229.

91. Michael Teets and Peter Murray, "Metasearch Authentication and Access Management," D-Lib Magazine 12, no. 6 (2006). Available online at www.dlib.org/dlib/june06/teets/06teets.html. [Accessed 20 May 2009.]

92. Agnew, Digital Rights Management.

93. Alan Robiette, "Managing Access to Electronic Information: Progress and Prospects," Serials 14, no. 3 (2001): 302.

94. Krieb, "You Can't Get There from Here," under "How Publishers and Aggregators Establish Access Control."

95. Primary Research Group, Survey of Library Database Licensing Practices, 22.

96. Kathy Mcgreevy, "Social Security Numbers and User Authentication," e-mail to LibLicenseL Mailing list, Nov. 3, 1997. Available online at www.library.yale.edu/ llicense/ListArchives/9711/ msg00001.html. [Accessed 12 November 2008].

97. Agnew, Digital Rights Management; Lynch, White Paper on Authentication and Access Management Issues.

98. Agnew, Digital Rights Management; Maria D.D. Collins and Patrick L. Carr, Managing the Transition from Print to Electronic Journals and Resources: A Guide for Library and Information Professionals (New York: Routledge, 2008).

99. Bide and Hing, User Identification and Authentication, 5. 
100. Lynch, White Paper on Authentication and Access Management Issues; interview data.

101. The Shibboleth Advantage (2003). Available online at http://shibboleth.internet2.edu/docs/ internet2-mace-shibboleth-advantage-200309.pdf. [Accessed 1 December 2008].

102. Shibboleth Architecture Technical Overview, eds. Tom Scavo and Scott Cantor (2005), 5-6. Available online at http://shibboleth.internet2.edu/docs/draft-mace-shibboleth-tech-overviewlatest.pdf. [Accessed 1 December 2008].

103. Terry Morrow, "Shibboleth: Raising the Standard for Access Control," presentation at Value in Acquisition Conference, London, UK, Feb. 27-28, 2006, available online at www. subscription-agents.org/conference/200602/Morrow.pps [Accessed 1 December 2008]; B. Douglas Blansit, "Beyond Password Protection: Methods for Remote Patron Authentication," Journal of Electronic Resources in Medical Libraries 4, no. 1 (2007): 185-94.

104. The Shibboleth Advantage; Morrow, "Shibboleth."

105. The University of Washington developed a mechanism to allows for IP authentication in addition to credential authentication, so technically walk-in use could be allowed in Shibboleth system (Holly Eggleston, "Beyond the IP Address: Shibboleth and Electronic Resources," presentation at ALA Midwinter 2008 LITA Standards IG, available online at www.negentropy. net/docs/Shib4Lib_alamw_w08_post.ppt [Accessed 1 December 2008]). However, if fine-grained access control becomes the norm, walk-in use may not necessarily be permitted by all providers.

106. For example, Jenkins and Thorborn, "Introduction: The Digital Revolution, the Information Citizen, and the Culture of Democracy."

107. Charles Leadbeater, "Living on Thin Air," in The Information Society Reader, ed. F. Webster (New York: Routledge, 2003), 21-30; Nico Stehr, "Modern Societies as Knowledge Societies," in G. Ritzer and B. Smart, eds. Handbook of Social Theory (London: Sage Publications, 2001), 494-508; Yoneji Masuda, "Image of the Future Information Society," in Managing in the Information Society: Releasing Synergy Japanese Style (Oxford, UK: Blackwell, 1990), 3-10,

108. Barbara M. Pope, "The Future of the Academic Library Serials Collection," Against the Grain 19, no. 5 (2007): 22-28.

109. Mark S. Frankel, Seizing the Moment: Scientists' Authorship Rights in the Digital Age, July 2002. Available online at www.aaas.org/spp/sfrl/projects/epub/finalrept.html. [Accessed 1 December 2008].

110. John Willinsky, The Access Principle: The Case for Open Access to Research and Scholarship (Cambridge, Mass.: MIT Press, 2006), 39-41.

111. Willinsky, Access Principle; Joseph E. Stiglitz, "Knowledge as a Global Public Good," in Global Public Goods: International Cooperation in the 21st Century, eds. I. Kaul, I. Grunberg, and M. Stern (New York: Oxford University Press, 1999), 308-26.

112. Phillip M. Davis, "Tragedy of the Commons Revisited: Librarians, Publishers, Faculty and the Demise of a Public Resource," Portal: Libraries and the Academy 3, no. 4 (2003): 547-62. 